\title{
RADIOGRAPHIC DETERMINATION OF THE CANINE ELBOW JOINT ANGLE IN COLLIMATED VIEWS
}

\author{
ALVES-PIMENTA Sofia ${ }^{1,3}$, COLAÇO Bruno ${ }^{1,3}$, GINJA Mário $^{2,3^{*}}$ \\ ${ }^{1}$ Department of Animal Science, ${ }^{2}$ Department of Veterinary Science, ${ }^{3} \mathrm{CITAB}$ - Centre for the Research \\ and Technology of Agro-Environmental and Biological Sciences, Universidade de Trás-os-Montes e \\ Alto Douro, Vila Real, Portugal.
}

(Received 10 April, Accepted 04 November 2020)

\begin{abstract}
The mediolateral flexed, extended, or neutral elbow radiographic views are commonly used in clinical practice. However, there is currently no standardized methodology to accurately measure the elbow joint angle in mediolateral images that include only the elbow joint and surrounding tissues. The main aim of this work is to compare elbow joint angles obtained from mediolateral radiographs that include the complete arm and forearm of the dog, with angles measured in radiographs including only the elbow. Ninety mediolateral views of elbow joints were obtained from 50 canine thoracic limbs, with 39 joints $<90^{\circ}, 30 \geq 90-\leq 120^{\circ}$ and $21>120^{\circ}$. Radiographs were centered on the elbow joint and include the shoulder and carpal joints. For each complete forelimb radiographic image, the elbow angle was measured using the methodology described in previous studies. Then, the digital images were cut to obtain only the joint and surrounding tissues, establishing a new set of anatomical landmarks to measure the joint angles: the lateral humeral epicondyle was used as an angular point, with the linking points being the nutritional orifice of the radius at the antebrachial interosseous space and the intersection point of the lateral supracondylar crest with the cranial humeral endosteum. There was a good agreement observed between the two elbow angle measurement methodologies. The intraclass correlation coefficient was statistically significant, with the lower limits of the $95 \%$ confidence interval (CI) at $>0.75$, and with zero being included in the standard error of the mean 95\% confidence interval in the Bland-Altman test. This elbow angle measurement methodology based on anatomic landmarks next to the elbow joint is accurate and may be used for clinical and research purposes.
\end{abstract}

Key words: Elbow dysplasia, mediolateral view, elbow angle, canine osteoarthritis.

\section{INTRODUCTION}

The mediolateral flexed, extended, or neutral elbow radiographic views are commonly used in clinical practice [1,2], and the International Elbow Working Group (IEWG) recommends the use of some of these views for screening of elbow dysplasia. However,

*Corresponding author: e-mail: mginja@utad.pt 
there is currently no standardized methodology to accurately measure the elbow joint angle in mediolateral views that include only the elbow joint and surrounding tissues. In the literature, there are only references to the radiographic measurement of the elbow angle when the image includes the shoulder and the carpal joints. This complete thoracic limb radiographic view is rarely performed by clinicians [3].

The elbow joint degree of flexion and extension changes both the contact between articular surfaces and the thoracic limb alignment and thereby influences the assessment of joint spaces [4-6]. The narrowing of the joint space detected on the elbow images is a radiographic finding used to quantify incongruity [1,7]. Malalignment of the elbow joint surfaces plays a potential role in the pathogenesis of medial coronoid disease and is associated with elbow dysplasia, leading to the development of secondary osteoarthritis $[8,9]$.

When planning some surgical treatment procedures, such as canine elbow arthroplasty, the elbow evaluation at $\sim 135^{\circ}$ of extension could be recommended to simulate a weight-bearing position [10]. Radiographic joint angle measurements are important to assess physiologic and pathologic changes [11-14]. For these purposes, it is essential to understand the normal radiographic anatomy in order to establish reference parameters and find landmarks for an accurate diagnosis of abnormal developments [15].

Jaegger et al. (2002), described a method to measure the amplitude of elbow angles by goniometry [3]. These authors evaluated the reliability of radiographic measurements including shoulder and carpal joints, comparing the results with goniometric measurements. These goniometric and radiographic methods are applied by clinicians and researchers [16]. However, this methodology cannot be used in clinical practice when radiographic images only include the elbow joint, distal humerus and proximal radius/ulna [16].

The purpose of the present study was to develop a methodology to determine elbow joint angles in the mediolateral radiographic images that cover only the joint and surrounding tissues. The elbow joint angles obtained in radiographs that include the shoulder, elbow and carpal joints were compared with similar angles measured in the same radiographs that include only the elbow joint, using new reference landmarks. We hypothesized that no differences exist between elbow angles measured in large and small radiographic images.

\section{MATERIAL AND METHODS}

\section{Inclusion criteria}

The dogs included were seen at the Veterinary Teaching Hospital of University of Trás-os- Montes and Alto Douro, between 2017 and 2018, with an elbow dysplasia diagnosis. To meet the inclusion criteria, dogs had to be over 12 months of age, present no clinical signs of forelimb disease based on their history and on orthopedic examination, and show an absence of radiographic signs of elbow dysplasia. The 
radiographs were evaluated for elbow dysplasia according to the International Elbow Working Group's guidelines. All procedures were approved and conducted in accordance with the Institutional Animal Care and Use Committee of our institution and with the European and Portuguese regulations for animal use and care (European Directive 2010/63/EU and National Decree-Law 113/2013). In addition, an informed consent was obtained from the animal owners included in this study.

\section{Image Acquisition}

The dogs were sedated with an intravenous administration of $0.005 \mathrm{mg} / \mathrm{kg}$ of dexmedetomidine hydrochloride (Orion Corporation, Espoo, Finland) and $0.2 \mathrm{mg} /$ kg butorphanol tartrate (Richter Pharma, Wels, Austria). Once sedated, one or two mediolateral elbow radiographic views were obtained from each forelimb at $<90^{\circ}, \geq 90$ - $\leq 120^{\circ}$ and $/$ or $>120^{\circ}$ joint angles, using a computed digital x-ray device (Fujifilm, FCR Prima, Tokyo, Japan). The animals were placed in lateral recumbence over the $\mathrm{x}$-ray table with the elbows directly on the cassette and the beam centered on the medial humeral epicondyle. The x-ray image was collimated to include the shoulder joint and the carpus [3]. The sedation was then reversed with an intramuscular injection of atipamizole hydrochloride (Orion Corporation, Espoo, Finland) dosed at the same volume as the dexmedetomidine hydrochloride.

\section{Digital Imaging Analysis}

The images were then exported onto a free DICOM digital manipulation software (Radiant, version 1.9.16, Medixant, Poznan, Poland) and the elbow angle measurements were performed by SA, a veterinarian with experience in elbow evaluation and measurements. These measurements were carried out on randomized radiographs, in two independent sessions, using the software's standard digital angle tool. In the first measurement session (S1), the amplitudes of the elbow angles were measured using anatomical references previously described: the angular point was set at the center of the lateral humeral epicondyle, then a line was drawn connecting it to the ulnar styloid process, as well as another line connecting it to the major humerus tubercle (Figure 1) $[3,17]$. The center of the lateral humeral epicondyle was located on radiographs at the intersection point between the opacity of the cranial border of the lateral humeral epicondyle with the humeral condyle. The ulnar styloid process was located craniocaudal midpoint of the antebrachium at the level of the ulnar epiphysis [3]. The center of the major humerus tubercle was defined at the level of the cranial end of the intertubercular groove.

The images were then prepared for the second measurement session (S2), where the original digital images were cut excluding the shoulder and the carpus, with only the elbow joint and surrounding tissues remaining. The new anatomical references for elbow angle measurement in S2 were the lateral humeral epicondyle (angular point) defined as described for $\mathrm{S} 1$, the nutritional orifice of the radius at the antebrachial 
interosseous space and the intersection point between the lateral supracondylar crest and the humeral endosteum cranial to trace the connecting lines (Figure 2).

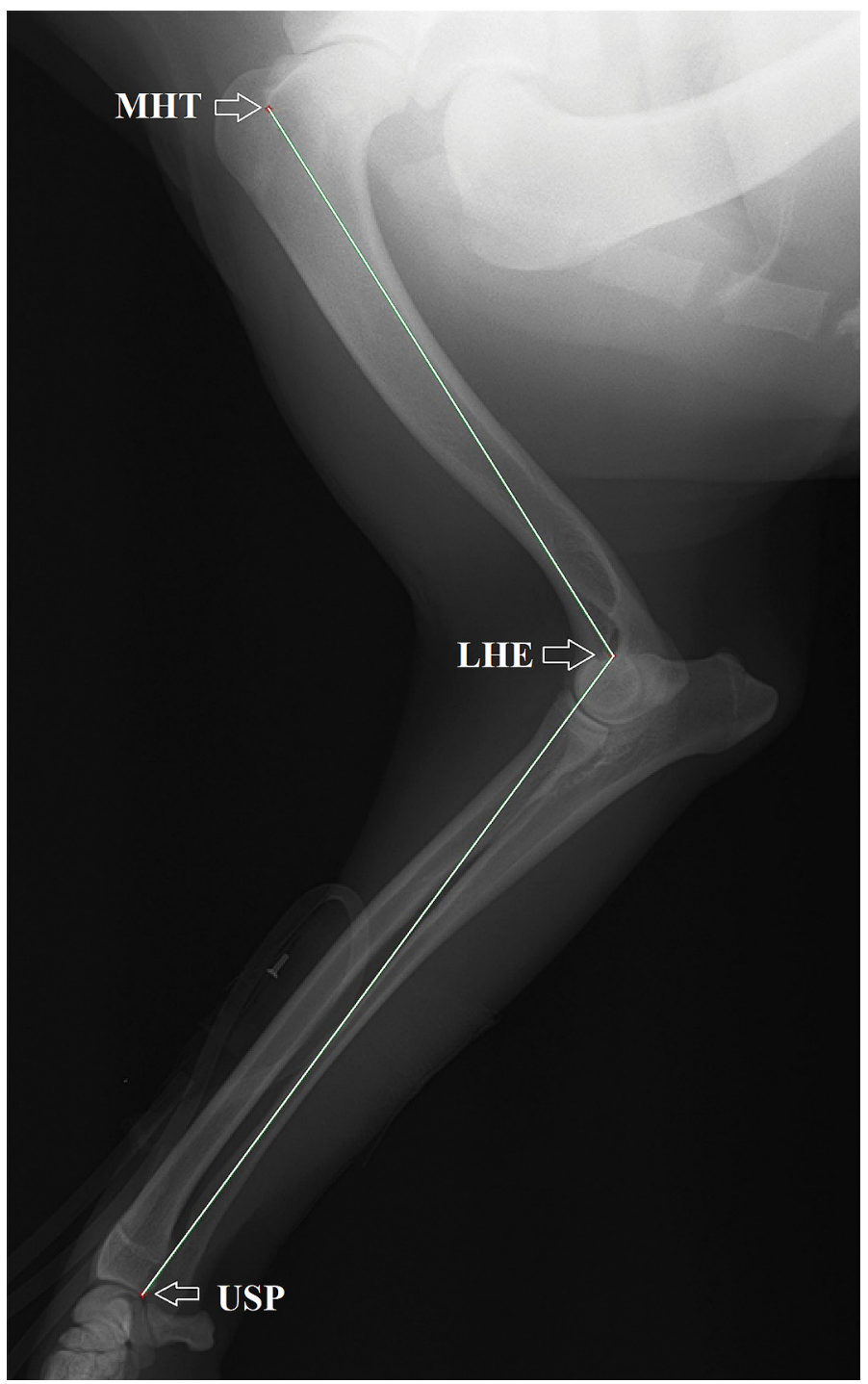

Figure 1. Anatomical references for measuring the amplitude of elbow angle using as angular point the centre of lateral humeral epicondyle (LHE), and a line linking it to the ulnar styloid process (USP), and other line linking it to the major humerus tubercle (MHT). 


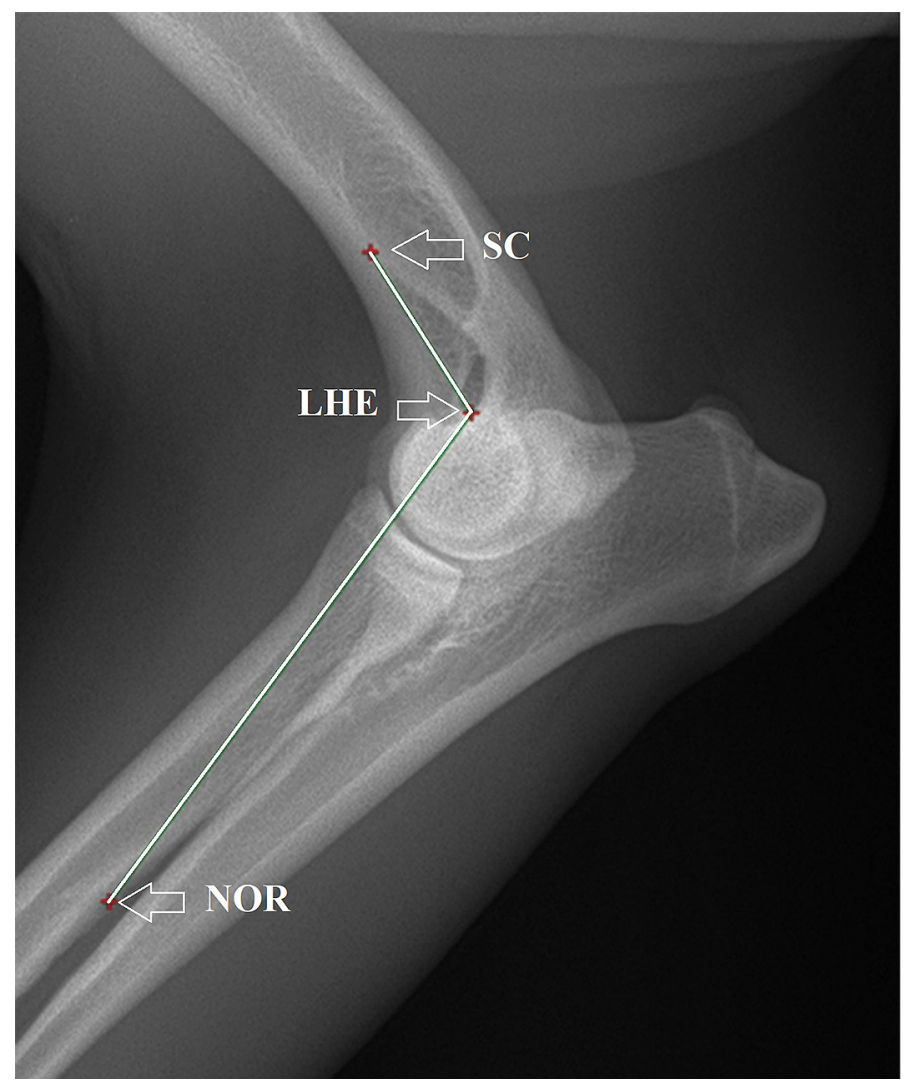

Figure 2. Anatomical references for measuring the angles amplitude using as angular point the lateral humeral epicondyle (LHE) and as linking points the nutritional orifice of the radius (NOR) at the antebrachial interosseous space and the intersection point of the lateral supracondylar crest and the cranial humeral endosteum (SC).

\section{Statistical Analysis}

The statistical analysis was performed using the SPSS software (SPSS Statistics for Windows, Version 23.0, IBM Corp., Armonk, NY, USA). Data were assessed for normality using the Shapiro-Wilk test. For statistical purposes, three different radiographic angular groups (G1, G2 and G3) were considered: G1 angle $<90^{\circ}, \mathrm{G} 2$ angle between $90-120^{\circ}$, and $\mathrm{G} 3$ angle $>120^{\circ}$. The intraclass correlation coefficient (ICC) and the Bland-Altman analysis were used to determine the elbow angle measurement reproducibility of S2 [18-20]. An ICC of 1 indicates perfect agreement, and an ICC of 0 indicates no agreement. A lower limit 95\% confidence interval (CI) of an ICC above 0.75 was defined as an adequate correlation [19].

To determine the limits of agreement (LA) according to the Bland-Altman method, we calculated the mean difference $(\bar{d})$ between pairs of measurements and its $95 \%$ $\mathrm{CI}$ as $\bar{d} \pm 2$ standard error of the mean (SEM). When this interval includes the 
zero value, the measurements are considered to be in agreement. Then, 95\% LA were estimated as $d \pm 1.96$ standard deviation (SD). A narrower $95 \% \mathrm{LA}$ is associated with a higher agreement between methods, and the measurements are considered to be equivalent $[18,20]$. All the data were analyzed using a commercially available software ${ }^{\mathrm{f}}$ and the significance was set at $p<0.05$.

\section{RESULTS}

Fifty thoracic limbs from 25 dogs were evaluated (90 elbow joints), 17 females and 8 males, with ages ranging from 1 to 11 years (mean age $\pm S D, 2.7 \pm 2.4$ years). Nine dogs belonged to the Estrela Mountain Dog breed (mean weight $36.9 \pm 2.9 \mathrm{Kg}$ ), 13 to the Portuguese Pointing Dog breed (mean weight $20.6 \pm 3.3 \mathrm{Kg}$ ) and 3 to the Transmontano Cattle Dog breed (mean weight $51.3 \pm 14 \mathrm{Kg}$ ).

Table 1. Range and mean \pm standard deviation of joint angle values obtained using the two methodologies of measurement (Sessions I and II), and intraclass correlation coefficients ( $95 \%$ confidence interval).

\begin{tabular}{cccc}
\hline $\begin{array}{c}\text { Measurement } \\
\text { comparison }\end{array}$ & Session I & Session II & ICC (95\% CI) \\
\hline Angle $<90^{\circ}$ & $\begin{array}{r}43 \text { to } 88^{\circ} \\
\left(64 \pm 14^{\circ}\right)\end{array}$ & $\begin{array}{r}43 \text { to } 89^{\circ} \\
\left(64 \pm 13^{\circ}\right)\end{array}$ & $0.99(0.99$ to 1.00$)$ \\
Angle between $90-120^{\circ}$ & $\begin{array}{r}92 \text { to } 120^{\circ} \\
\left(110 \pm 7^{\circ}\right)\end{array}$ & $\begin{array}{r}91 \text { to } 119^{\circ} \\
\left(109 \pm 7^{\circ}\right)\end{array}$ & $0.97(0.94$ to 0.99$)$ \\
Angle $>120^{\circ}$ & $\begin{array}{r}122 \text { to } 134^{\circ} \\
\left(128 \pm 3^{\circ}\right)\end{array}$ & $\begin{array}{c}121 \text { to } 137^{\circ} \\
\left(128 \pm 4^{\circ}\right)\end{array}$ & $0.95(0.87$ to 0.98$)$ \\
\hline
\end{tabular}

$\mathrm{CI}=$ confidence interval; ICC $=$ intraclass correlation coefficient

Table 2. Mean differences of elbow angle values verified between the two methodologies of measurement.

\begin{tabular}{lcccc}
\hline Differences & $\overline{\boldsymbol{d}} \pm \mathbf{S E M}\left({ }^{\circ}\right)$ & $\overline{\boldsymbol{d}} \mathbf{9 5 \%} \mathbf{C I}\left({ }^{\circ}\right)$ & $\overline{\boldsymbol{d}} \pm \mathbf{S D}\left({ }^{\circ}\right)$ & $\mathbf{9 5 \%} \mathbf{L A}\left({ }^{\circ}\right)$ \\
\hline Angle $<90^{\circ}$ & $-0.26 \pm 0.35$ & -0.96 to 0.44 & $-0.26 \pm 2.19$ & -4.56 to 4.04 \\
Angle between $90-120^{\circ}$ & $0.70 \pm 0.43$ & -0.17 to 1.58 & $0.70 \pm 2.38$ & -3.97 to 5.38 \\
Angle $>120^{\circ}$ & $0.32 \pm 0.34$ & -0.38 to 1.03 & $0.32 \pm 1.55$ & -2.71 to 3.37 \\
\hline
\end{tabular}

$\mathrm{CI}=$ confidence interval; $\bar{d}=$ mean differences; $\mathrm{SEM}=$ standard error of the mean; $\mathrm{SD}=$ standard deviation; LA = limits of agreement.

The number of joints evaluated were 39 in the $\mathrm{G} 1$ angle $<90^{\circ}, 30$ in the $\mathrm{G} 2$ angle between $90-120^{\circ}$ and 21 in the G3 angle $>120^{\circ}$. In S1 measurement session using the conventional forelimb landmarks, the range and mean \pm SD of the elbow angles in G1, G2, and G3 were respectively the following: 43 to $88^{\circ}, 64 \pm 14^{\circ} ; 92$ to $120^{\circ}, 110$ $\pm 7^{\circ} ; 122$ to $134^{\circ}, 128 \pm 3^{\circ}$. The reproducibility of S2 using only the elbow joint and surrounding tissues was statistically adequate for the three angle groups (Table 1 and 
2). The ICC was 0.99 in the $\mathrm{G} 1$ angle $<90^{\circ}, 0.94$ in the $\mathrm{G} 2$ angle between $90-120^{\circ}$, and 0.87 in the $\mathrm{G} 3$ angle $>120^{\circ}$, with the $95 \%$ CI lower limit of $0.87(\mathrm{P}<0.05)$. The Bland-

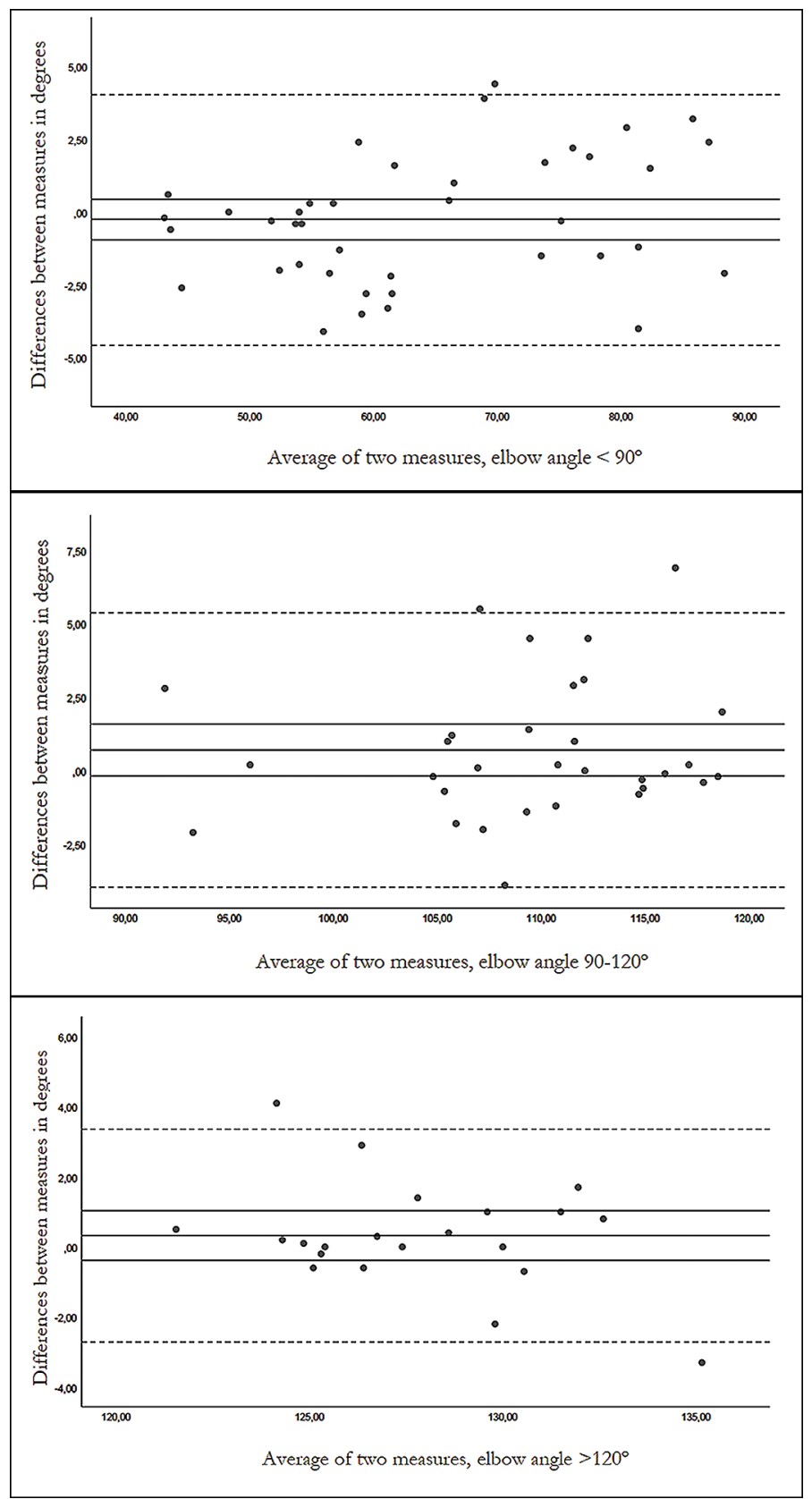

Figure 3. Bland-Altman plots showing the differences in measures between the two methods in the Session 1 and 2 used to evaluate the joint angles. In the top, elbow angle $<90^{\circ}$, mean difference $=-0.26^{\circ}$; in the middle, elbow angle between $90-120^{\circ}$, mean difference $=0.70^{\circ}$; and below, elbow angle $>120^{\circ}$, mean difference $=0.32^{\circ}$. 
Altman analysis showed mean differences between the two measurement methods of $0.26^{\circ}$ in the group angle $<90^{\circ}$, of $0.70^{\circ}$ in the group angle between $90-120^{\circ}$, and of 0.32 in the group angle $>120^{\circ}$, with zero being included in all the mean $95 \% \mathrm{CI}$ $(\mathrm{P}>0.05)$ (Table 2). The agreement between the two measurement methods in each measurement group is represented using the Bland-Altman plots in Figure 3.

\section{DISCUSSION}

Radiographic assessment of the elbow joint angle in dogs is challenging and lacks objective and reliable measurement landmarks. In the present work, the authors describe a methodology to calculate joint angles in mediolateral radiographs including only the elbow, which is commonly used in clinical practice for screening purposes and for planning treatments. The sample was divided in three research groups to obtain a normality of data using the Shapiro-Wilk test and to be able to use parametric statistical tests.

Our results demonstrate a good agreement between the two elbow angle measurement methodologies and good reliability of the anatomical references used on the S2 evaluation session. The elbow angle measurements obtained in S1 and S2 were statistically similar, as the ICCs were above 0.95 with the $95 \%$ CI lower limits over 0.87 (Table 1). Currently, the association of ICC determination with the Bland and Altman analysis is recommended to measure agreement, since the former estimates the intraclass correlation and the second studies the differences between the methods [18-20]. Differences between methods were close to zero in all the groups studied and $95 \%$ CI were very tight and included the zero, meaning there is no significant bias of the method proposed (Fig. 3). Therefore, both measurement methodologies can be considered interchangeable. These results may be of particular interest for the assessment of elbow congruity based on the measurement of joint spaces and for planning treatments of elbow joint diseases, when only the elbow joint and surrounding tissues are visible in the radiographic study. The anatomical protrusions lateral humeral epicondyle, humeral ulnar styloid process and the major humerus tubercle on mediolateral elbow radiographic views were not well defined in previous works. The recommended landmarks for its location in mediolateral elbow radiographs were based on previous anatomical and image analyses using radiopaque points. As the recommended landmarks in collimated elbow views are well identified in the radiographs (lateral humeral epicondyle, nutritional radius orifice and the intersection point between the lateral supracondylar crest and the humeral endosteum), we think that the elbow angle measurement is objective and will not require much experience on the part of the evaluator.

The certification of the elbow joints based on the IEWG standards requires specific mediolateral views of the elbow. An effort to identify predisposing factors for elbow arthrosis has been made in recent years, with the joint incongruity sometimes being evaluated measuring the joint spaces [1]. However, this joint incongruity evaluation 
presented some limitations, as elbow spaces change depending on the limb grade of flexion or extension [21]. To improve accuracy, elbow space measurements should be associated with the level of joint flexion or extension [22]. Adequate technical radiographic quality also requires the x-ray beam to be centered on the medial humeral epicondyle, which results in superimposition of both humeral condyles.

Computed tomography and arthroscopy are considered the most accurate imaging modalities for early diagnosis of canine medial coronoid disease [23]. However, radiography is the mainstay for screening elbow dysplasia or for the initial diagnosis of clinical elbow disease [24], and some reports showed a good sensitivity and specificity of radiography in determining elbow incongruity [25]. The definitive diagnosis of medial coronoid disease using radiography can be challenging in young growing dogs [26]. The clinical manifestation of the medial coronoid disease has been reported as early as three months of age [27], whereas radiographic changes associated are difficult to identify before seven months of age [8]. The first radiographic changes are mainly associated with secondary elbow osteoarthritis [21,28].

A potential limitation of this study is the reduced number of breeds included. The anatomical conformation of dog breeds has some differences that can interfere with the repeatability of our results. Therefore, we recommend further similar studies to be performed in other breeds and for the use of this methodology for clinical or research purposes to be carefully considered for now.

\section{CONCLUSION}

To the best of the authors' knowledge the present paper is the first report on joint angle assessment through landmarks established in radiographs that include only the elbow joint and surrounding tissues. The method proposed is accurate and adequately reproduces the elbow angles obtained with large images of the complete limb. Further studies are necessary to assess the influence of the elbow joint angle in the measurement of articular spaces, as well as how they vary in different positions.

\section{Acknowledgements}

This work was supported by National Funds by FCT - Portuguese Foundation for Science and Technology, under the projects UIDB/04033/2020 and Scientific Employment Stimulus - Institutional Call - CEECINST/00127/2018 UTAD.

\section{Authors' contributions}

SAP carried out acquisition of data (Radiographs), measurements in radiographs, have been involved in drafting of the manuscript and revising it critically for important intellectual content. $\mathrm{BC}$ has been involved in drafting of the manuscript and revising it critically for important intellectual content. MG carried out acquisition of data 
(Radiographs), has been involved in drafting of the manuscript and revising it critically for important intellectual content. All authors read and approved the final manuscript.

\section{Declaration of conflicting interests}

The author(s) declared no potential conflicts of interest with respect to the research, authorship, and/or publication of this article.

\section{REFERENCES}

1. Samoy Y, Gielen I, Saunders J, van Bree H, Van Ryssen B: Sensitivity and specificity of radiography for detection of elbow incongruity in clinical patients. Vet Radiol Ultrasound 2012, 53 (3):236-244.

2. Alves-Pimenta S, Ginja MM, Colaco B: Role of elbow incongruity in canine elbow dysplasia: advances in diagnostics and biomechanics. Vet Comp Orthop Traumatol 2019, 32 (2):8796.

3. Jaegger G, Marcellin-Little DJ, Levine D: Reliability of goniometry in Labrador Retrievers. Am J Vet Res 2002, 63 (7):979-686.

4. Cuddy LC, Lewis DD, Kim SE, Conrad BP, Banks SA, Horodyski M, Fitzpatrick N, Pozzi A: Contact mechanics and three-dimensional alignment of normal dog elbows. Vet Surg 2012, 41 (7):818-828.

5. Burton NJ, Warren-Smith CM, Roper DP, Parsons KJ: CT assessment of the influence of dynamic loading on physiological incongruency of the canine elbow. J Small Anim Pract 2013, 54 (6):291-298.

6. Goodrich ZJ, Norby B, Eichelberger BM, Friedeck WO, Callis HN, Hulse DA, Kerwin SC, Fox DB, Saunders WB: Thoracic limb alignment in healthy labrador retrievers: evaluation of standing versus recumbent frontal plane radiography. Vet Surg 2014, 43 (7):791-803.

7. Lappalainen AK, Hyvarinen T, Junnila J, Laitinen-Vapaavuori O: Radiographic evaluation of elbow incongruity in Skye terriers. J Small Anim Pract 2016, 57 (2):96-9.

8. Mostafa AA, Nolte I, Wefstaedt P: Radiographic determination of humeroradial, humeroulnar, and radioulnar subluxation indices to quantify elbow incongruence in dogs confirmed to have medial coronoid disease. Res Vet Sci. 2019, 126:83-88.

9. Samoy Y, Van Vynckt D, Gielen I, van Bree H, Duchateau L, Van Ryssen B: Arthroscopic findings in 32 joints affected by severe elbow incongruity with concomitant fragmented medial coronoid process. Vet Surg 2012, 41 (3):355-361

10. Gosling MJ, Martinez-Taboada F, Te Lintelo G, Burton NJ: Evaluation of the milling technique on the component-bone interface in the TATE elbow. Vet Surg 2019, 48 (1):5056.

11. Goldfarb CA, Patterson JM, Sutter M, Krauss M, Steffen JA, Galatz L: Elbow radiographic anatomy: measurement techniques and normative data. J Shoulder Elbow Surg 2012, 21 (9):1236-1246.

12. Bush MA, Bowlt K, Gines JA, Owen MR: Effect of use of different landmark methods on determining stifle angle and on calculated tibial tuberosity advancement. Vet Comp Orthop Traumatol 2011, 24 (3):205-210. 
13. Lau SF, Hazewinkel HA, Voorhout G: Radiographic and computed tomographic assessment of the development of the antebrachia and elbow joints in Labrador Retrievers with and without medial coronoid disease. Vet Comp Orthop Traumatol 2015, 28 (3):186-192.

14. Breiteneicher AH, Norby B, Schulz KS, Kerwin SC, Hulse DA, Fox DB, Saunders WB: The effect of sliding humeral osteotomy $(\mathrm{SHO})$ on frontal plane thoracic limb alignment: an ex vivo canine cadaveric study. Vet Surg 2016, 45 (8):1095-1107.

15. Wood MC, Fox DB, Tomlinson JL: Determination of the mechanical axis and joint orientation lines in the canine humerus: a radiographic cadaveric study. Vet Surg 2014, 43 (4):414-447.

16. Alves-Pimenta S, Colaco B, Fernandes AM, Goncalves L, Colaco J, Melo-Pinto P, Ginja MM: Radiographic assessment of humeroulnar congruity in a medium and a large breed of dog. Vet Radiol Ultrasound 2017, 58 (6):627-633.

17. Evans H. In: HE E, editor. Miller's anatomy of the dog. 4rd edition ed. Philadelphia, PA: Saunders; 2012. p. 158-183.

18. Bland JM, Altman DG: Statistical methods for assessing agreement between two methods of clinical measurement. Lancet (London, England) 1986, 1 (8476):307-10.

19. Lee J, Koh D, Ong CN: Statistical evaluation of agreement between two methods for measuring a quantitative variable. Comput Biol Med 1989, 19 (1):61-70.

20. Bland JM, Altman DG: Measuring agreement in method comparison studies. Stat Methods Med Res 1999, 8 (2):135-160.

21. Skinner OT, Warren-Smith CM, Burton NJ, Parsons KJ: Computed tomographic evaluation of elbow congruity during arthroscopy in a canine cadaveric model. Veterinary and comparative orthopaedics and traumatology : VCOT. 2015;28(1):19-24.

22. Mostafa A, Nolte I, Wefstaedt P: Quantitative radiographic evaluation of elbow incongruity in Labrador and Golden Retrievers with confirmed medial coronoid disease. Vet Comp Orthop Traumatol 2019, 32 (1):10-17.

23. Alves-Pimenta S, Ginja MM, Fernandes AM, Ferreira AJ, Melo-Pinto P, Colaco B: Computed tomography and radiographic assessment of congruity between the ulnar trochlear notch and humeral trochlea in large breed dogs. Vet Comp Orthop Traumatol. 2017, 30 (1):8-14.

24. Fitzpatrick N, Yeadon R: Working algorithm for treatment decision making for developmental disease of the medial compartment of the elbow in dogs. Vet Surg 2009, 38 (2):285-300.

25. Blond L, Dupuis J, Beauregard G, Breton L, Moreau M: Sensitivity and specificity of radiographic detection of canine elbow incongruence in an in vitro model. Vet Radiol Ultrasound 2005, 46 (3):210-216.

26. Lau SF, Wolschrijn CF, Hazewinkel HA, Siebelt M, Voorhout G: The early development of medial coronoid disease in growing Labrador retrievers: radiographic, computed tomographic, necropsy and micro-computed tomographic findings. Vet J 2013, 197 (3):724730.

27. Lau SF, Hazewinkel HA, Grinwis GC, Wolschrijn CF, Siebelt M, Vernooij JC, Voorhout G, Tryfonidou MA: Delayed endochondral ossification in early medial coronoid disease (MCD): a morphological and immunohistochemical evaluation in growing Labrador retrievers. Vet J 2013, 197 (3):731-738.

28. Coppieters E, Seghers H, Verhoeven G, Gielen I, Samoy Y, de Bakker E, Van Ryssen B: Arthroscopic, computed tomography, and radiographic findings in 25 dogs with lameness after arthroscopic treatment of medial coronoid disease. Vet Surg 2016, 45 (2):246-253. 


\title{
RADIOGRAFSKO SNIMANJE LAKATNOG ZGLOBA PASA KOLIMATIZOVANIM PROJEKCIJAMA
}

\author{
ALVES-PIMENTA Sofia, COLAÇO Bruno, GINJA Mário
}

U kliničkoj praksi se često koriste mediolateralne savijene, ispružene i radiografske projekcije u neutralnom položaju lakta. Međutim, ne postoje standardizovane metode kojima bi se ispravno obavilo merenje ugla lakatnog zgloba u mediolateralnoj projekciji koja obuhvata isključivo lakatni zglob i okolno tkivo. Osnovni cilj rada je bio da se obavi poređenje uglova lakatnog zgloba, dobijenih mediolaterlnom radiografijom koja je potpuno obuhvatala prednji ekstremitet psa, pri čemu su se merenja uglova dobijenih radiografijom odnosila samo na lakat. Ukupno je dobijeno 90 mediolateralnih snimaka projekcija lakatnog zgloba, od 50 udova, pri čemu je 39 zglobova imalo vrednosti ugla manje od $90^{\circ}, 30$ zglobova $\leq 90^{\circ}$ i 21 zgloba $>120^{\circ}$. Radiografski snimci su centrirani na lakatni zglob pri čemu su bili obuhvaćeni rameni i karpalni zglob. Za svaki od potpunih radiografskih snimaka prednjeg ekstremiteta, ugao lakatnog zgloba je meren uz primenu metodologije koja je opisana u prethodnim studijama. Posle toga, digitalni snimci su isečeni da bi se dobili samo snimci zgloba i okolnog tkiva. $\mathrm{Na}$ taj način je uspostavljen novi set anatomskih granica za merenje uglova zgloba: lateralni epikondilus humerusa je korišćen kao teme ugla sa povezanim tačkama radijusa antebrahijalnog interkosnog prostora i tačka preseka lateralnog suprakondilarnog grebena sa kranijalnim endoostom humerusa. Postojala je dobra povezanost između dve metodologije merenja uglova lakatnog zgloba. Koeficijent korelacije u okviru klase bio je statistički značajan pri čemu su donje granične vrednosti za 95\% interval pouzdanosti (CI) bile $>0,75$ pri čemu je nulta vrednost bila uključena u standardnu grešku srednje vrednosti pri 95\% CI, Bland-Altman testa. Metodologija merenja ugla lakatnog zgloba, zasnovana na anatomskim graničnim tačkama neposredno uz lakatni zglob, je tačna metoda koja može da se primenjuje kako za klinička ispitivanja tako i za naučno istraživačke svrhe. 